\title{
Trophoblast Differentiation Affects Crucial Nutritive Functions of Placental Membrane Transporters
}

\author{
Rona Karahoda ${ }^{1 \dagger}$, Jonas Zaugg ${ }^{2,3 \dagger}$, Barbara Fuenzalida ${ }^{2}$, Sampada Kallol ${ }^{2,3}$, \\ Ruedi Moser-Haessig ${ }^{4}$, Frantisek Staud ${ }^{1}$ and Christiane Albrecht ${ }^{2,3 *}$
}

${ }^{1}$ Department of Pharmacology and Toxicology, Faculty of Pharmacy in Hradec Kralove, Charles University, Hradec Kralove, Czech Republic, ${ }^{2}$ Institute of Biochemistry and Molecular Medicine, University of Bern, Bern, Switzerland, ${ }^{3}$ Swiss National Centre of Competence in Research, NCCR TransCure, University of Bern, Bern, Switzerland, ${ }^{4}$ Division of Gynecology and Obstetrics, Lindenhofgruppe, Bern, Switzerland

\section{OPEN ACCESS}

Edited by:

Mariafrancesca Scalise,

University of Calabria, Italy

Reviewed by:

Susanna Bodoy,

Institute for Research in Biomedicine,

Spain

Matteo Moretto Zita

Vertex Pharmaceuticals

(United States), United States

*Correspondence:

Christiane Albrecht christiane.albrecht@ibmm.unibe.ch

${ }^{\dagger}$ These authors have contributed equally to this work and share first authorship

Specialty section:

This article was submitted to

Cellular Biochemistry,

a section of the journal

Frontiers in Cell and Developmental

Biology

Received: 22 November 2021 Accepted: 25 January 2022

Published: 22 February 2022

Citation:

Karahoda R, Zaugg J, Fuenzalida B, Kallol S, Moser-Haessig R, Staud F and Albrecht $C$ (2022) Trophoblast Differentiation Affects Crucial Nutritive

Functions of Placental

Membrane Transporters.

Front. Cell Dev. Biol. 10:820286.

doi: $10.3389 /$ fcell.2022.820286
Cytotrophoblasts are progenitor cells that proliferate and fuse to form the multinucleated syncytiotrophoblast layer, implicated in placental endocrine and transport functions. While membrane transporters play a critical role in the distribution of nutrients, hormones, and xenobiotics at the maternal-fetal interface, their selectivity to the syncytiotrophoblast layer is poorly characterized. We aimed to evaluate the regulation of placental transporters in response to trophoblast differentiation in vitro. Experiments were carried out in isolated primary human trophoblast cells before and after syncytialization. Gene expression of six molecular markers and thirty membrane transporters was investigated by qPCR analysis. Subsequently, functional expression was evaluated for proteins involved in the transplacental transfer of essential nutrients i.e., cholesterol (ABCA1, ABCG1), glucose (SLC2A1), leucine (SLC3A2, SLC7A5), and iron (transferrin receptor, TfR1). We identified that human chorionic gonadotropin, placental lactogen, endoglin, and cadherin-11 serve as optimal gene markers for the syncytialization process. We showed that trophoblast differentiation was associated with differential gene expression (mostly up-regulation) of several nutrient and drug transporters. Further, we revealed enhanced protein expression and activity of ABCG1, SLC3A2, SLC7A5, and TfR1 in syncytialized cells, with ABCA1 and GLUT1 displaying no change. Taken together, these results indicate that the syncytiotrophoblast has a dominant role in transporting essential nutrients cholesterol, leucine, and iron. Nonetheless, we present evidence that the cytotrophoblast cells may also be linked to transport functions that could be critical for the cell fusion processes. Our findings collectively yield new insights into the cellular functions associated with or altered by the trophoblast fusion. Importantly, defective syncytialization could lead to nutrient transfer imbalance, ultimately compromising fetal development and programming.

Keywords: trophoblast, placental barrier, membrane transport, nutrients, fetal programming, pregnancy pathology, cell differentiation

\section{INTRODUCTION}

The placenta is the first and largest fetal organ created during human development. In the first weeks of pregnancy, trophectoderm, the precursor of placental cells, interacts with the uterine epithelium allowing implantation (Burton and Fowden 2015). This process leads to the generation of mononucleated cytotrophoblast cells (CTBs), precursors of extravillous and villous trophoblasts. 
In the anchoring villus, CTBs subsequently differentiate by fusion to the multinucleated syncytiotrophoblast (STB) layer, representing the primary maternal-fetal exchange site. These complex processes are highly orchestrated, involving biochemical and morphological changes to support the integrity of the placental exchange surface (Knofler et al., 2019). Importantly, as a highly endocrine organ, the secretion of hormones and proteins can serve as markers to distinguish the placental cellular source and play a role in deciphering processes associated with trophoblast differentiation. Nonetheless, despite the high importance, this field of research is still in its infancy, mainly due to the lack of suitable cellular models (Knofler et al., 2019).

With the fetus entirely dependent on the maternal supply of nutrients, the placental nutrient exchange is critical for proper fetal development and programming (Costa 2016). The placenta is equipped with a battery of transporters that facilitate the transfer of nutrients and control the transplacental disposition of many drugs (Vähäkangas and Myllynen 2009; Koepsell 2020). Two families of membrane transport proteins are recognized: the ATP-binding cassette (ABC) and the solute carrier (SLC) transporter family. The ABC transporters actively pump their substrates out of the trophoblast cells into the maternal circulation, using ATP as an energy source; thus, they play a critical role in fetal protection against drugs and other toxins (Dallmann et al., 2019). Additionally, ABC transporters orchestrate the biodistribution of several endogenous substrates, including steroid hormones, lipids, cholesterol, and factors involved in inflammatory and immunological responses (Bloise et al., 2016). SLC transporters mainly facilitate the transport of charged and uncharged organic molecules as well as inorganic ions into the trophoblast cells and they are involved in materno-fetal nutrient translocation and metabolic sensing (Walker et al., 2017; Zhang et al., 2018). Several members of this diverse transporter family are functionally expressed in the trophoblast cells, mediating the transport of amino acids, glucose, monoamines, organic cations and anions, and a wide range of drugs and toxins (Balkovetz et al., 1989; Illsley 2000; Sata et al., 2005; Cleal et al., 2018).

Altered placental transport function represents one of the critical mechanisms implicated with Developmental Origins of Health and Disease (Barker et al., 1993; Barker et al., 2010). Maternal under- or over-nutrition elicits metabolic changes, which have a profound regulatory effect on placental nutrient transport. These adaptive mechanisms subsequently increase the offspring's risk of metabolic and cardiovascular disturbances in adulthood (Gaccioli et al., 2013). Additionally, impaired placental transporters are implicated in placental pathologies, including gestational diabetes mellitus, pre-eclampsia, and fetal growth restriction (Desoye et al., 2011; Huang et al., 2018; Zaugg et al., 2020b).

Although several ABC and SLC transporters have been described in the placenta (for summary see Table 1), limited evidence still exists on their localization, developmental changes, and the extent of functionality within the fetoplacental unit. Understanding the expression patterns and functional activity of placental transporters is essential in providing insights into their role in reproductive functions and pregnancy-associated pathologies. Emerging evidence highlights that placental transporters may participate in intracellular signaling and cell differentiation (Apáti et al., 2016; Bloise et al., 2016). Nonetheless, while there is a general concept that the STB represents the main transport surface in the fetoplacental unit, only a limited number of studies have investigated the transport capacities of trophoblast cells in relation to their differentiation state (Evseenko et al., 2006; Kallol et al., 2018a; Kallol et al., 2018b; Zaugg et al., 2020a).

In this context, we sought to determine the expression and functional activity of several membrane transport proteins in primary CTBs isolated from the human term placenta. When seeded on extracellular matrix-coated dishes, CTBs spontaneously fuse over time into multinuclear STB (Kliman et al., 1986), thus providing an ideal physiological model to study processes associated with cell differentiation. Several molecular markers have been suggested to identify villous trophoblast cells, such as cytokeratin, ERVW-1, hCG, CDH11, ENG, MUC1, and hPL (Huppertz 2006). While immunohistochemistry is often used for this purpose, we sought to determine the mRNA expression of selected markers to observe whether their expression reflects the differentiation stage in vitro. Next, we screened for differential expression of several classes of nutrient and drug transport genes associated with trophoblast syncytialization. The selection of transporters (Table 1) was based on experimental evidence that these proteins influence the transplacental transfer of essential nutrients (e.g., glucose, lipids, amino acids), micronutrients (e.g., iron), and vitamins (e.g., folate, thiamine) that are of crucial importance for placental and fetal development and metabolic programming. Lastly, we investigated the functional regulation of membrane proteins that transport representative substrates of selected nutrient classes (i.e., cholesterol, leucine, and iron), thus providing insights into the transport functions associated with or altered by the trophoblast fusion process.

\section{MATERIALS AND METHODS}

\subsection{Tissue Collection}

Human term placenta samples (gestational age at delivery: 38-40) were collected from uncomplicated pregnancies after elective cesarean section at the Division of Gynecology and Obstetrics, Lindenhofgruppe, Bern, Switzerland. All women signed informed consent, and the study was performed according to the Declaration of Helsinki, with the approval of the Ethics Committee of the Canton of Bern (Basec Nr. 2016-00250).

\subsection{Primary Trophoblast Isolation, Characterization, and Culture}

Villous trophoblast cells were isolated using a previously established protocol from human term placenta samples (Kliman et al., 1986; Kallol et al., 2018a). Briefly, villous tissue was subjected to three enzymatic digestion steps at $37^{\circ} \mathrm{C}$ with $0.25 \%$ trypsin (Sigma, United States) and $300 \mathrm{IU} / \mathrm{ml}$ deoxyribonuclease I (Sigma, United States). The obtained cell 
TABLE 1 | Overview of key placental ABC and SLC transport systems with associated genes and gene products, evaluated in the study.

\begin{tabular}{|c|c|c|c|c|c|c|}
\hline Transporter family & $\begin{array}{l}\text { Gene } \\
\text { name }\end{array}$ & Protein name & Aliases & $\begin{array}{l}\text { Transport } \\
\text { type }\end{array}$ & Substrates & References \\
\hline \multirow[t]{2}{*}{ Cholesterol efflux transporter } & ABCA1 & ABCA1 & ABC1, TGD, CERP & A & cholesterol, phospholipids, & Kallol and Albrecht \\
\hline & ABCG1 & ABCG1 & ABC8 & A & cholesterol & (2020) \\
\hline \multirow[t]{2}{*}{ Drug transporter } & ABCB1 & $P-g p$ & ABC20, CD243, MDR1 & A & $\begin{array}{l}\text { steroids, bilirubin, bile acids, } \\
\text { anticancer drugs, protease } \\
\text { inhibitors, drugs of abuse }\end{array}$ & $\begin{array}{l}\text { Vähäkangas et al. } \\
\text { (2011) }\end{array}$ \\
\hline & ABCG2 & BCRP & ABCP, BCRP1, MXR & A & $\begin{array}{l}\text { estrones, bile acids, glyburide, } \\
\text { cimetidine, statins, anticancer drugs }\end{array}$ & \\
\hline $\begin{array}{l}\text { Facilitative glucose } \\
\text { transporter }\end{array}$ & SLC2A1 & GLUT1 & & $\mathrm{F}$ & $\begin{array}{l}\text { glucose, galactose, mannose, } \\
\text { glucosamine }\end{array}$ & IIIsley (2000) \\
\hline Folate transporter & SLC19A1 & RFC & RFC1, RFT & $\begin{array}{l}\text { E/organic } \\
\text { phosphates }\end{array}$ & reduced folates, antifolates & $\begin{array}{l}\text { Zhao and Goldman } \\
\text { (2013) }\end{array}$ \\
\hline \multirow[t]{2}{*}{ Thiamine transporter } & SLC19A2 & THTR1 & $\operatorname{ThTr} 1$ & $\mathrm{~F}$ & thiamine & \\
\hline & SLC19A3 & THTR2 & ThTr2 & $\mathrm{F}$ & thiamine & \\
\hline $\begin{array}{l}\text { Proton-coupled metal ion } \\
\text { transporter }\end{array}$ & SLC11A2 & DMT1 & NRAMP2, DCT1 & $\mathrm{C} / \mathrm{H}^{+}$ & $\begin{array}{l}\mathrm{Fe}^{2+}, \mathrm{Cd}^{2+}, \mathrm{Co}^{2+}, \mathrm{Cu}^{1+}, \mathrm{Mn}^{2+}, \mathrm{Ni}^{2+} \\
\mathrm{Pb}^{2+}, \mathrm{Zn}^{2+}\end{array}$ & $\begin{array}{l}\text { Montalbetti et al. } \\
\text { (2013) }\end{array}$ \\
\hline \multirow[t]{3}{*}{ Metal ion transporter } & SLC39A8 & $\begin{array}{l}\text { ZIP8, } \\
\text { BIGM103, } \\
\text { LZT-Hs6 }\end{array}$ & & & $\mathrm{Zn}, \mathrm{Cd}, \mathrm{Mn}$ & Jeong and Eide (2013) \\
\hline & SLC39A14 & $\begin{array}{l}\text { ZIP14, } \\
\text { LZT-Hs4 }\end{array}$ & & & $\mathrm{Zn}, \mathrm{Fe}, \mathrm{Mn}, \mathrm{Cd}$ & \\
\hline & SLC40A1 & FPN1 & MTP1, IREG1 & $\mathrm{F} ?$ & $\mathrm{Fe}^{2+}$ & $\begin{array}{l}\text { Montalbetti et al. } \\
(2013)\end{array}$ \\
\hline \multirow[t]{2}{*}{$\begin{array}{l}\text { Proton oligopeptide co- } \\
\text { transporter }\end{array}$} & SLC15A1 & PEPT1 & $\begin{array}{l}\text { oligopeptide transporter } \\
\text { 1, } \mathrm{H}^{+} \text {-peptide } \\
\text { transporter } 1\end{array}$ & $\mathrm{C} / \mathrm{H}^{+}$ & $\begin{array}{l}\text { di- and tri-peptides, protons, beta- } \\
\text { lactam antibiotics }\end{array}$ & Smith et al. (2013) \\
\hline & SLC15A2 & РEPT2 & $\begin{array}{l}\text { oligopeptide transporter } \\
2, \mathrm{H}^{+} \text {-peptide } \\
\text { transporter } 2\end{array}$ & $\mathrm{C} / \mathrm{H}^{+}$ & $\begin{array}{l}\text { di- and tri-peptides, protons, beta- } \\
\text { lactam antibiotics }\end{array}$ & \\
\hline \multirow{3}{*}{$\begin{array}{l}\text { Transporters for anionic } \\
\text { amino acids }\end{array}$} & SLC1A2 & GLT-1, EAAT2 & System $X_{A G}^{-}$ & $\mathrm{C} / \mathrm{Na}^{+}, \mathrm{H}^{+}, \mathrm{K}^{+}$ & Glu, Asp & Kanai et al. (2013) \\
\hline & SLC1A3 & $\begin{array}{l}\text { GLAST, } \\
\text { EAAT1 }\end{array}$ & System $X_{A G}^{-}$ & $\mathrm{C} / \mathrm{Na}^{+}, \mathrm{H}^{+}, \mathrm{K}^{+}$ & Glu, Asp & \\
\hline & SLC7A11 & $x \mathrm{CT}$ & [4F2hc], system $x c^{-}$ & $\begin{array}{l}\mathrm{E} \text { (Cys } \\
\text { against Glu) }\end{array}$ & cystine (anionic form), glutamate & Fotiadis et al. (2013) \\
\hline \multirow{2}{*}{$\begin{array}{l}\mathrm{Na}^{+} \text {-dependent transporters } \\
\text { for neutral amino acids }\end{array}$} & SLC38A1 & SNAT1 & ATA1, NAT2, SAT1 & $\mathrm{C} / \mathrm{Na}^{+}$ & Gin, Ala, Asn, Cys, His, Ser & Schiöth et al. (2013) \\
\hline & SLC38A2 & SNAT2 & ATA2, SAT2 & $\mathrm{C} / \mathrm{Na}^{+}$ & $\begin{array}{l}\text { Ala, Asn, Cys, Gln, Gly, His, Met, } \\
\text { Pro, Ser }\end{array}$ & \\
\hline \multirow[t]{4}{*}{$\begin{array}{l}\mathrm{Na}^{+} \text {-independent } \\
\text { transporters for neutral } \\
\text { amino acids }\end{array}$} & SLC7A5 & LAT1 & [4F2hc], 4F2lc, system L & $E$ & $\begin{array}{l}\text { large neutral amino acids, } \\
\text { triiodothyronine (T3), thyroxine (T4), } \\
\text { DOPA, BCH }\end{array}$ & $\begin{array}{l}\text { Fotiadis et al. (2013), } \\
\text { Scalise et al. (2018) }\end{array}$ \\
\hline & SLC7A8 & LAT2 & [4F2hc], system L & $E$ & neutral amino acids, T3, T4, BCH & \\
\hline & SLC43A1 & LAT3 & POV1 & $\mathrm{F}$ & $\begin{array}{l}\text { branched chain amino acids, amino } \\
\text { alcohols }\end{array}$ & Bodoy et al. (2013) \\
\hline & SLC43A2 & LAT4 & & $\mathrm{F}$ & $\begin{array}{l}\text { branched chain amino acids, amino } \\
\text { alcohols }\end{array}$ & \\
\hline \multirow{4}{*}{$\begin{array}{l}\text { Cationic amino acids and } \\
\text { large neutral L-amino acids } \\
\text { transporter }\end{array}$} & SLC7A1 & CAT-1 & ATRC1, system $y^{+}$ & $\begin{array}{l}\text { F (non- } \\
\text { obligatory E) }\end{array}$ & cationic L-amino acids & Fotiadis et al. (2013) \\
\hline & SLC7A6 & $\mathrm{y}^{+}$LAT2 & [4F2hc], system y $\mathrm{y}^{+} \mathrm{L}$ & $E$ & $\begin{array}{l}\text { cationic amino acids ( } \mathrm{Na}^{+} \\
\text {independent), large neutral amino } \\
\text { acids ( } \mathrm{Na}^{+} \text {dependent) }\end{array}$ & \\
\hline & SLC7A7 & $\mathrm{y}^{+} \mathrm{LAT1}_{1}$ & [4F2hc], system y $\mathrm{y}^{+} \mathrm{L}$ & $E$ & $\begin{array}{l}\text { cationic amino acids ( } \mathrm{Na}^{+} \\
\text {independent), large neutral L-amino } \\
\text { acids ( } \mathrm{Na}^{+} \text {dependent) }\end{array}$ & \\
\hline & SLC7A9 & $\mathrm{b}^{0,+} \mathrm{AT}$ & {$[\mathrm{rBAT}]$, system $b^{0,+}$} & $E$ & $\begin{array}{l}\text { cationic amino acids, large neutral } \\
\text { amino acids }\end{array}$ & \\
\hline \multirow{2}{*}{$\begin{array}{l}\text { Heavy subunits of the } \\
\text { heteromeric amino acid } \\
\text { transporters (SLC7) }\end{array}$} & SLC3A1 & rBAT & NBAT, D2H & $E$ & $\begin{array}{l}\text { system } b^{0,+} \text {, heterodimerizes with } \\
\text { light subunit SLC7A9 }\end{array}$ & $\begin{array}{l}\text { Fotiadis et al. (2013), } \\
\text { Napolitano et al. }\end{array}$ \\
\hline & SLC3A2 & 4F2hc & CD98hc, FRP & $\mathrm{E}$ & $\begin{array}{l}\text { systems } L, y^{+} L, x^{-} \text {and asc with } \\
\text { light subunits SLC7A5-8 and } \\
\text { SLC7A10-11 }\end{array}$ & (2015) \\
\hline
\end{tabular}


suspension was overlayed on fetal bovine serum (Seraglob, Switzerland), centrifuged, and the pellet was resuspended on Dulbecco's Modified Eagle's Medium (high glucose; Gibco, United Kingdom). Subsequently, a discontinuous Percoll $^{\circledR}$ gradient was used to separate the cells. The purity of the isolated cells was evaluated by staining for cytokeratin-7 (93\% positivity), vimentin (4\% positivity), and E-cadherin (75\% positivity) using flow cytometry as previously described (Kallol et al., 2018a). Collected cells were seeded in CellBIND ${ }^{\circledR}$ plates (Costar, United States) and cultured in Dulbecco's Modified Eagle Medium (high glucose) with $10 \% \quad$ FBS and $1 \%$ antibiotic-antimitotic. CTB stage is represented by cells cultured for $8 \mathrm{~h}$ after seeding, whereas the STB stage is obtained by spontaneous fusion of CTBs over $72 \mathrm{~h}$ of culturing (with daily change of medium). hCG secretion by CTB and STB was measured in the cell culture medium using the human hCG (intact) ELISA kit (Sigma, United States), following the manufacturer's instructions.

\subsection{Quantitative PCR Analysis}

Total RNA was isolated from primary human trophoblast cells (CTB and STB stage) using Trizol reagent (Invitrogen, United Kingdom). RNA concentration and purity were determined spectrophotometrically using the NanoDrop 1000 Spectrophotometer (Thermo Fisher Scientific, United States). Subsequently, RNA was reverse transcribed to cDNA with the $\mathrm{GoScript}^{\mathrm{TM}}$ Reverse Transcriptase System (Promega, United States) according to the manufacturer's instructions. PCR analysis was carried out using the $\mathrm{ViiA}^{\mathrm{TM}} 7$ RT-PCR System (Applied Biosystems, United States) and the SYBR ${ }^{\circledR}$ Green PCR master mix detection kit (Promega, United States), as previously described (Kallol et al., 2018b). The primers used are listed in Supplementary Table S1. The mRNA expression of target genes was normalized against the expression of tyrosine 3monooxygenase/tryptophan 5-monooxygenase activation protein, zeta polypeptide (YWHAZ), stably expressed during trophoblast differentiation as previously described (Kallol et al., 2018b). Subsequently, relative expression to the undifferentiated cells was calculated and the results are expressed as $2^{-\Delta \Delta \mathrm{Ct}}$ or as median $\log _{2}$ Fold Change (FC).

\subsection{Protein Expression Analysis by Western Blot}

Cells (CTB and STB stage) were lysed in protein extraction buffer (100 mmol/L NaCl, 0.5\% Triton X-100, 1\% SDS, 50 mmol/L Tris/ $\mathrm{HCl}, \mathrm{pH}$ 7.4) containing a mixture of protease inhibitors. Extracts were sonicated, and the protein content was determined using the Pierce BCA Assay Kit (Thermo Fisher Scientific, United States). 50-70 $\mu \mathrm{g}$ of proteins were separated as described (Fuenzalida et al., 2018) by polyacrylamide gel electrophoresis (8\%), transferred to nitrocellulose membrane (Protran BA-83; Sigma-Aldrich, United States), and probed with primary rabbit polyclonal antiABCA1 (1:500, $18 \mathrm{~h}, 4^{\circ} \mathrm{C}$; Novus Biological, United States), antiABCG1 (1:500, $18 \mathrm{~h}, 4^{\circ} \mathrm{C}$; 1945-1, Epitomics, United States), antiSLC7A5/LAT1 (1:500, 18 h, $4^{\circ} \mathrm{C}$; 85226, Abcam, United Kingdom), anti SLC3A2/4F2hc $\left(1: 1000,18 \mathrm{~h}, 4^{\circ} \mathrm{C}\right.$; sc-376815, Santa Cruz
Biotechnology, United States), anti-SLC2A1/GLUT1 (1:1000, $18 \mathrm{~h}, 4^{\circ} \mathrm{C}$; 07-1401, Millipore, United States) and anti-CD71/ TfR1 (1:1000, $18 \mathrm{~h}, 4^{\circ} \mathrm{C}$; GTX102596, GeneTex, United States). The corresponding signal was visualized after incubation with antirabbit/anti-mouse IgG secondary antibody (1:20,000, 2 h, RT; 92668071/926-32210, LI-COR, United States) by chemiluminescence (ODYSSEY Imaging System, LI-COR Biosciences, United States) and normalized to $0.1 \%(\mathrm{w} / \mathrm{v})$ Ponceau $\mathrm{S}$ in $5 \%$ acetic acid (v/v) staining (P7170, Sigma). Ponceau S-stained blots can be found in Supplementary Figure S1.

\subsection{Lipoprotein Isolation}

For efflux assays, lipoproteins from non-pregnant donors were isolated by ultracentrifugation as described (Sreckovic et al., 2013). Briefly, sucrose (final concentration: 10\%), EDTA $(10 \mathrm{mmol} / \mathrm{L}, \quad \mathrm{pH} \quad 7.4), \quad$ aprotinin $(2 \mu \mathrm{g} / \mathrm{ml})$ and phenylmethylsulfonyl fluoride $(1 \mathrm{mmol} / \mathrm{L})$ were added to serum. The serum density was adjusted with $\mathrm{KBr}$ to $1.24 \mathrm{~g} / \mathrm{ml}$. PBS $(1.006 \mathrm{~g} / \mathrm{ml})$ was added over the samples to generate a density gradient by ultracentrifugation (rotor SW55Ti, 287000 $\mathrm{RCF}, 15^{\circ} \mathrm{C}, 4 \mathrm{~h}$ ), from which LDL, HDL, and the lipoproteindepleted serum (LPDS) were isolated. After dialysis in saline solution $\left(150 \mathrm{mmol} / \mathrm{L} \mathrm{NaCl}, 0.34 \mathrm{mmol} / \mathrm{L}\right.$ EDTA, pH 7.4, $4^{\circ} \mathrm{C}$, $48 \mathrm{~h}), \mathrm{LDL}$ and $\mathrm{HDL}$ were stored at $4^{\circ} \mathrm{C}$ in a sealed tube saturated with nitrogen. The protein concentration was determined using the Pierce BCA Protein Assay Kit (Thermo Fisher Scientific, United States). The isolation efficiency was determined by SDSPAGE separation followed by Coomassie R-250 staining and western blot analysis for ApoB and ApoA-I.

\subsection{Cholesterol Efflux Assays}

The efflux of $\left[{ }^{3} \mathrm{H}\right]$-cholesterol from trophoblast cells to ApoA-I or HDL was determined with minor modifications as described (Kallol et al., 2018a; Fuenzalida et al., 2020). In brief, cells were seeded at a density of $0.3 \times 10^{6}$ cells $/ \mathrm{cm}^{2}$ in 24-well plates and allowed to attach for $8 \mathrm{~h}$ for CTB and $48 \mathrm{~h}$ for STB. Then cells were pre-incubated for $24 \mathrm{~h}$ with Dulbecco's Modified Eagle Medium (high glucose) containing 10\% FBS supplemented with $\left[{ }^{3} \mathrm{H}\right]$-cholesterol $(0.5 \mu \mathrm{Ci} / \mathrm{ml})$. Subsequently, cells were washed with PBS supplemented with BSA-FFA $(2 \mathrm{mg} / \mathrm{ml})$. Next, cells were incubated at $37^{\circ} \mathrm{C}$ for $6 \mathrm{~h}$ with non-pregnant isolated HDL $(50 \mu \mathrm{g} / \mathrm{ml})$ or ApoA-I $(10 \mu \mathrm{g} / \mathrm{ml}$; Sigma-Aldrich, United States). Finally, the culture medium was recovered, and the cells were lysed with $\mathrm{KOH}$. The efflux activity was estimated as the fraction of radioactive signal in the medium compared to the total signal in the medium and cells. Acceptor-mediated efflux is calculated by subtracting efflux without acceptor from efflux with acceptor.

\subsection{Leucine Uptake}

Leucine uptake was determined based on a published method (Häfliger et al., 2018), as previously described (Zaugg et al., 2021). Primary trophoblast cells were incubated in $\mathrm{Na}^{+}$-free Hank's buffer (125 mM choline chloride, $25 \mathrm{mM}$ HEPES, $4.8 \mathrm{mM} \mathrm{KCl}$, $1.2 \mathrm{mM} \mathrm{MgSO}_{4}, 1.2 \mathrm{mM} \mathrm{KH} \mathrm{KO}_{4}, 1.3 \mathrm{mM} \mathrm{CaCl}, 5.6 \mathrm{mM}$ glucose, $\mathrm{pH} 7.4)$ containing $1 \mu \mathrm{Ci} / \mathrm{ml}\left[{ }^{3} \mathrm{H}\right]-\mathrm{L}-[3,4,5-3 \mathrm{H}(\mathrm{N})]$ leucine (PerkinElmer, United States) and unlabeled L-leucine 
at a final concentration of $167.2 \mu \mathrm{mol} / \mathrm{L}$. Leucine uptake was stopped by three washing steps, and cell lysis was achieved by adding the scintillation solution (MicroScint-20, PerkinElmer, United States) and plate shaking for $90 \mathrm{~min}$ at room temperature. Finally, radioactivity was determined using the TopCount ${ }^{\circledR}$ $\mathrm{NXT}^{\mathrm{TM}}$ Scintillation and Luminescence Counter (PerkinElmer, United States).

\subsection{Transferrin-Mediated Iron Uptake}

The experimental procedure and analysis of transferrin-mediated iron uptake were adapted from Gambling et al. (2001), as previously described (Zaugg et al., 2020b). In brief, ${ }^{55} \mathrm{FeCl}_{3}$ (PerkinElmer, Germany)-labeled uptake solution was prepared by dissolving human Apo-Tf in a balanced salt solution as previously reported (Zaugg et al., 2020b). Tf binding was carried out at $37^{\circ} \mathrm{C}$ for $2 \mathrm{~h}$. Subsequently, the cells were washed and equilibrated for $30 \mathrm{~min}$ at $37^{\circ} \mathrm{C}$ before the diluted uptake solution was added. The final iron concentration was $179.8 \mathrm{nmol} / \mathrm{L}$. Iron uptake was stopped at defined time points, and cell lysis was achieved by adding the scintillation solution (MicroScint-20, PerkinElmer, United States) and plate shaking for $90 \mathrm{~min}$ at room temperature. Radioactivity was measured by TopCount ${ }^{\circledR} \mathrm{NXT}^{\mathrm{TM}}$ Scintillation and Luminescence Counter (PerkinElmer, United States), and iron uptake was calculated as previously described (Zaugg et al., 2020b).

\subsection{Statistical Evaluation and Graphical Presentation}

Data analysis and graphical presentation were performed using the GraphPad Prism ${ }^{\circledR}$ software (GraphPad, United States). Expression and functional data were evaluated using nonparametric $t$-tests (Mann-Whitney test), whereas Two-Way ANOVA assessed time-dependent leucine and iron uptake.

\section{RESULTS}

\subsection{Expression and Secretion of Syncytial Markers}

Initially, mononucleated CTBs and the multinucleated STB layer (differentiated in vitro over a 72-h culture period) were analyzed for the expression of reported markers indicative of the syncytialization process (Huppertz 2006). Specifically, the expression of human chorionic gonadotropin (hCG), human placental lactogen (hPL), cadherin 11 (CDH11), endoglin (ENG), mucin-1 (MUC1), and syncytin-1 (ERVW-1) was investigated (Table 2). As expected, we observed a significant upregulation in hCG, hPL, and ENG gene expression at the STB stage compared to CTBs. Likewise, hCG protein release at $72 \mathrm{~h}$ was significantly higher in the differentiated cells, confirming the physiological characteristics of our in vitro model. On the other hand, while CDH11 showed a tendency towards higher expression in STB $(p=0.052)$, MUC1 and ERVW-1 were transcriptionally similar in both cell states.
TABLE 2 | Evaluation of mRNA expression and protein secretion of commonly used syncytialization markers.

\begin{tabular}{lcc}
\hline Marker & $\log _{\mathbf{2}}{ }^{\mathrm{FC}}$ & $\boldsymbol{p}$-value \\
\hline hCG mRNA & $8.87(5.86-9.98)$ & $p=0.0005$ \\
hCG secretion (ng/ml) & $1.87(0.98-2.22)$ & $p=0.002$ \\
hPL mRNA & $1.60(1.06-2.75)$ & $p=0.0034$ \\
CDH11 mRNA & $1.49(0.11-3.57)$ & $p=0.052$ \\
ENG mRNA & $2.26(0.63-4.11)$ & $p=0.0068$ \\
MUC1 mRNA & $-1.38(-2.24-0.41)$ & $p=0.19$ \\
ERWW-1 mRNA & $-0.081(-0.69-0.83)$ & $p>0.99$
\end{tabular}

Gene expression of human chorionic gonadotropin ( $\mathrm{CCG}$ ), human placental lactogen (hPL), cadherin 11 (CDH11), endoglin (ENG), mucin-1 (MUC1), and syncytin-1 (ERWW-1) was evaluated by qPCR analysis and normalized to the expression of YWHAZ. hCG, protein secretion was measured using an ELISA kit. Presented results are $\log _{2} F C$, expression/secretion in STB stage compared to the CTB counterpart. Data are shown as median with IQR; $n \geq 10$. Statistical significance was evaluated using nonparametric t-test (Mann-Whitney test).

\subsection{Effect of Trophoblast Differentiation on the Gene Expression of Membrane Transporters}

Thirty transporters of the $\mathrm{ABC}$ and SLC superfamily were evaluated for their expression patterns in CTB and STB cells (Figures 1,2). Concerning lipid transporters (Figure 1A), ABCA1 and ABCG1 were selected as primary transporters mediating cholesterol efflux from cells to lipid-poor ApoA-I and HDL particles, respectively (Kallol and Albrecht 2020). The expression of both transporters was significantly upregulated in the differentiated cells. Similarly, the expression of two other efflux transporters from the $\mathrm{ABC}$ superfamily, namely ABCG2 and ABCB1, facilitating the transport of several substrates (including drugs and environmental chemicals (Vähäkangas and Myllynen 2009)), was significantly upregulated in the STB stage (Figure 1B).

Several members of the SLC superfamily were examined, particularly those mediating the transport of glucose, iron, vitamins, peptides, and amino acids. mRNA expression of glucose transporter SLC2A1 was significantly upregulated in the differentiated trophoblast cells (Figure 1C). Of the SLC19A gene family, only SLC19A1 (mediating the transport of reduced folate) showed higher expression in STB. In contrast, thiamine transporters SLC19A2 and SLC19A3 were similarly expressed in CTB and STB cells (Figure 1D). While placental iron transport mechanisms are still not fully elucidated, we investigated the expression of five key proteins reported in the literature (Sangkhae and Nemeth 2019), comprising four transporters of the SLC superfamily (SLC11A2, SLC40A1, SLC39A8, SLC39A14; Figure 1E) and transferrin receptor (TfR1; Figure 1F). Thereof SLC40A1 (Figure 1E) and TfR1 (Figure 1F) showed differential expression patterns, with higher expression in CTBs and downregulated expression in the STB stage. Additionally, the expression of peptide transporters (SLC15A family) was analyzed, revealing significant upregulation of the SLC15A1 transporter at the STB stage, but no change for SLC15A2 (Figure 1G). 


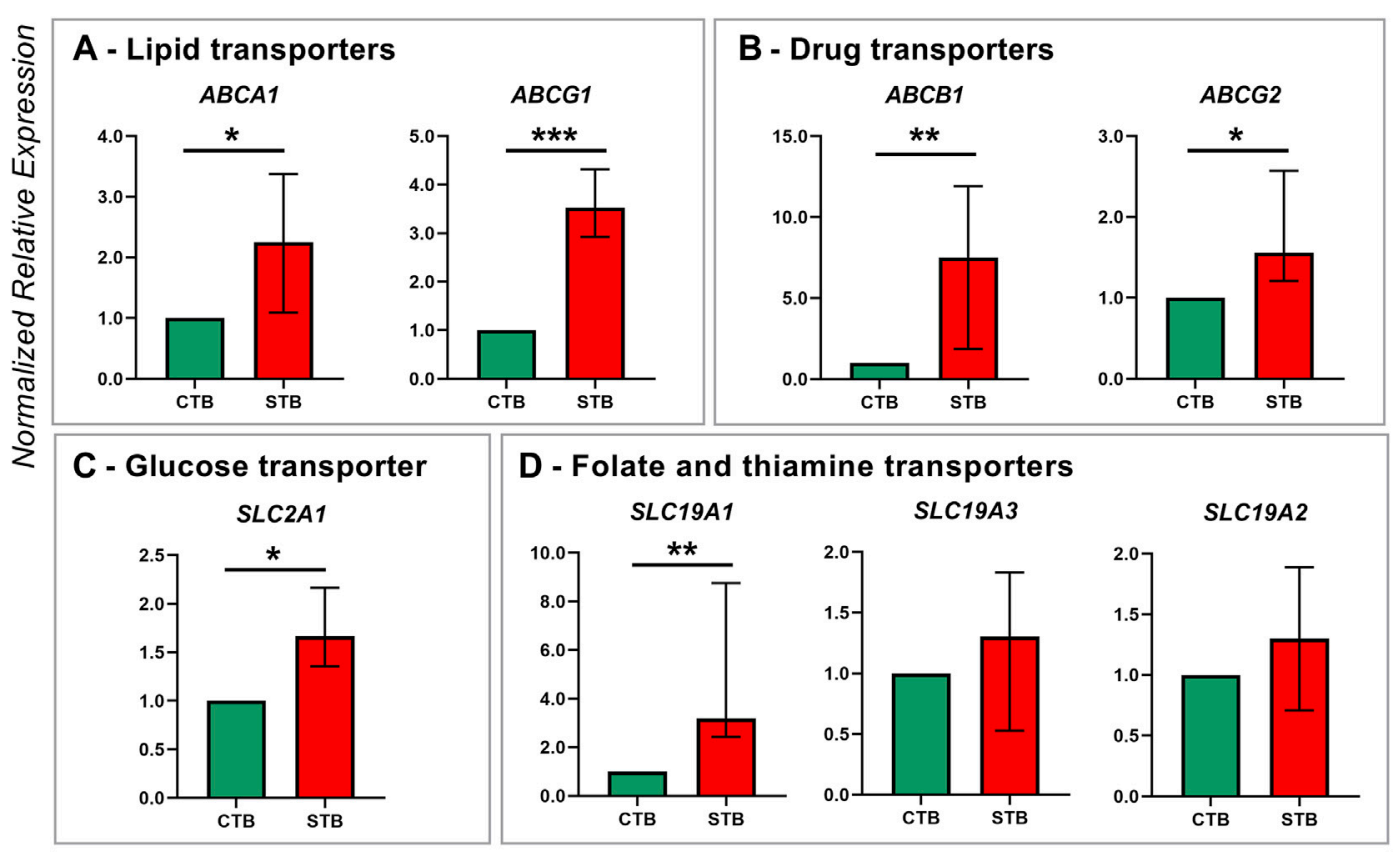

\section{E - Iron transporters}

SLC11A2

SLC40A1

SLC39A8

SLC39A14
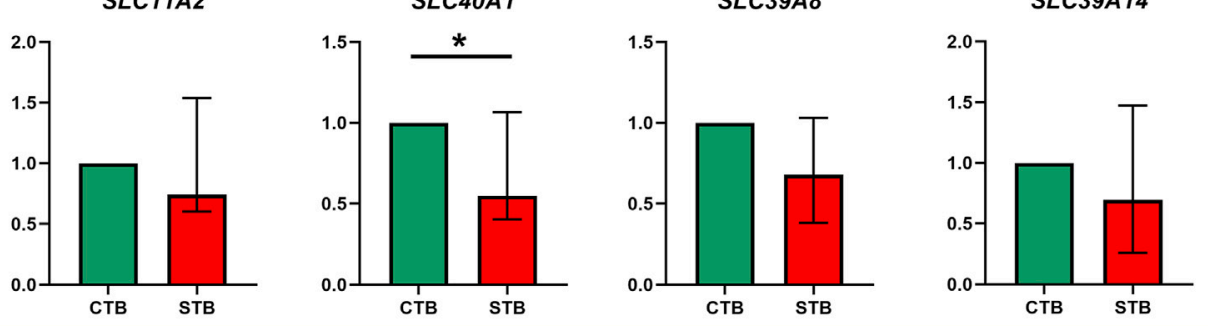

F - Transferrin receptor

G - Oligopeptide transporters

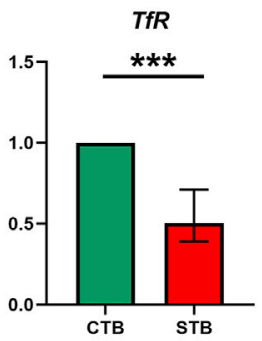
SLC15A1

SLC15A2

FIGURE 1 | Membrane transporter gene expression in human term primary CTBs and upon spontaneous differentiation to STB in vitro. mRNA expression was evaluated by qPCR analysis for members of the following transport classes: lipids (A), drugs (B), glucose (C), folate and thiamine (D), iron (E), and peptide (G); additionally, expression of the iron uptake receptor was assessed (F). Target gene expression was normalized to the reference gene $\mathrm{YWHAZ}$ and the results are shown as median with IQR expression in differentiated cells relative to the undifferentiated counterpart; $n \geq 7$ for each stage. Statistical significance was evaluated using nonparametric t-tests (Mann-Whitney test): ${ }^{\star} p \leq 0.05,{ }^{\star \star} p \leq 0.01,{ }^{* \star *} p \leq 0.001$.

Regarding amino acid transporters, five families from the SLC superfamily were examined and they include members of the SLC1A, SLC3A, SLC7A, SLC38A, and SLC43A families (Figure 2). The STB cell stage was mainly associated with an upregulation of transporters for cationic and large neutral amino acid transporters SLC7A1, SLC7A6, and SLC7A9 (Figure 2C).
Similarly, the expression of heavy subunits of heteromeric amino acid transporters SLC3A1 and SLC3A2 was significantly increased in the differentiated cells (Figure 2D). On the other hand, the expression of transporters for anionic (SLC1A2, SLC1A3, SLC7A11; Figure 2A), and neutral amino acids (SLC7A5, SLC7A8, SLC38A1, SLC38A2, SLC43A2; 


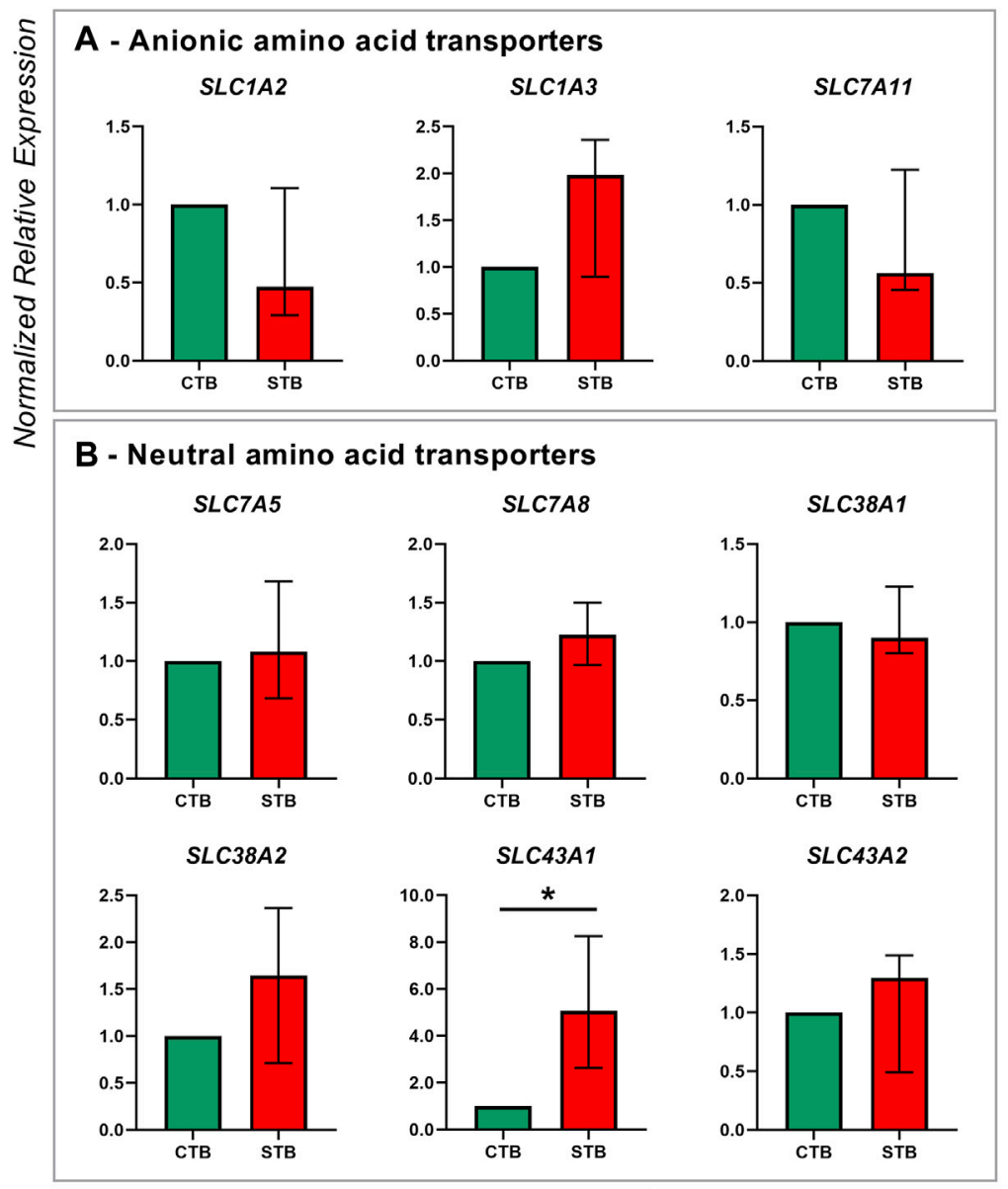

\section{C - Cationic and large neutral amino acid transporters}
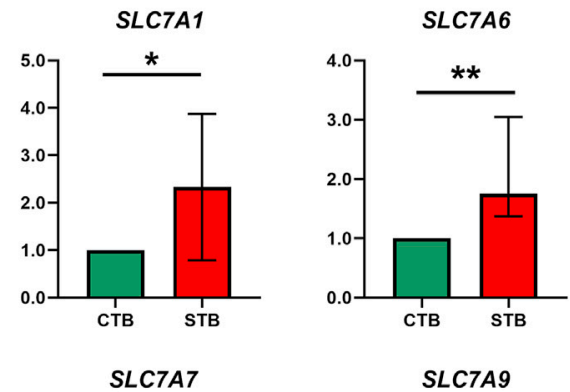

\section{D - Heavy subunits of heteromeric amino acid transporters}
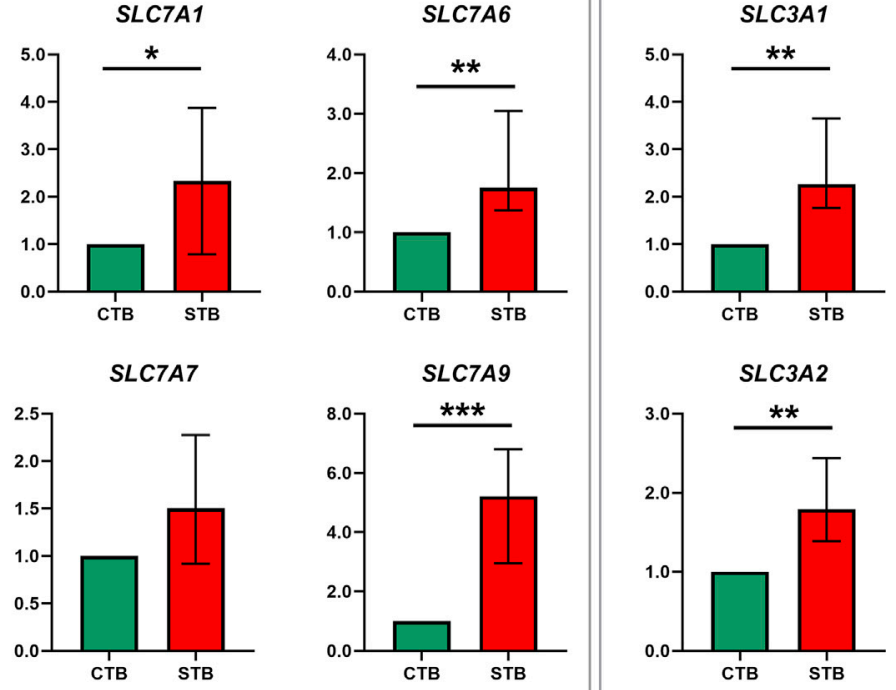

FIGURE 2 | Amino acid transporter gene expression in human term primary CTBs and upon spontaneous differentiation to STB in vitro. Classification of amino acid transporters was based on the substrate specificity: anionic (A), neutral (B), cationic and large neutral (C), and heavy subunits of the heterodimeric amino acid transporters (D). Target gene expression was normalized to the reference gene YWHAZ and the results are shown as median with IQR expression in differentiated cells relative to the undifferentiated counterpart; $n \geq 7$ for each stage. Statistical significance was evaluated using nonparametric $t$-tests (Mann-Whitney test): ${ }^{*} p \leq 0.05$, ${ }^{\star *} p \leq 0.01,{ }^{* \star *} p \leq 0.001$. 


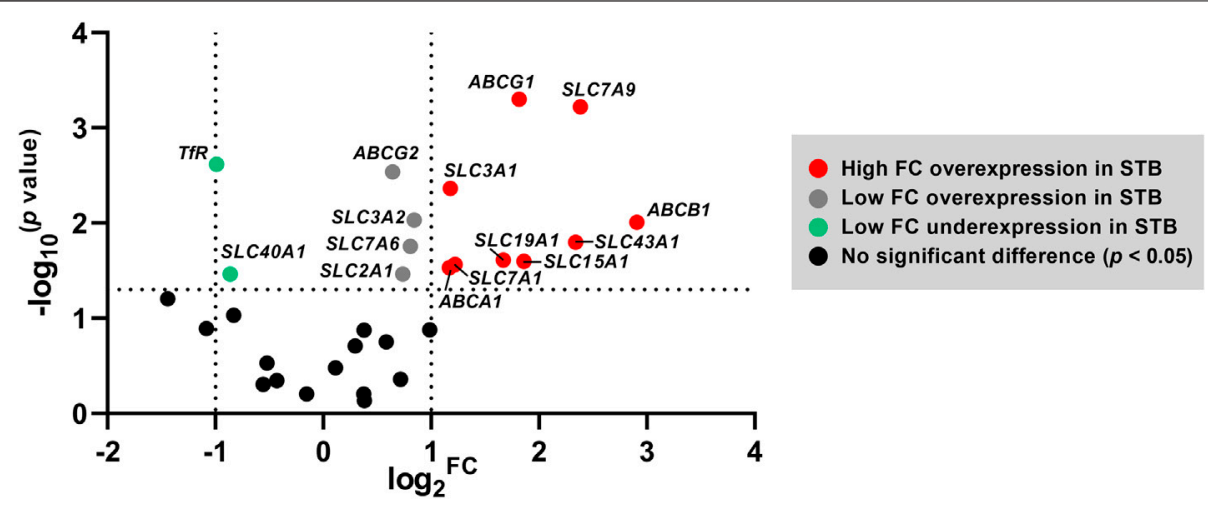

FIGURE 3 | Volcano plot highlighting the set of genes that are differentially expressed at the STB stage. The horizontal axis represents median log 2 fold change (FC), and the vertical axis - $\log _{10}$ transformed $p$ values; statistical analysis was evaluated by nonparametric t-tests (Mann-Whitney test). The dotted lines represent the upper and lower limit of the threshold FC (which was set to 2) and the threshold $p$-value (set as $<0.05$ ).

Figure 2B), was unaltered by the spontaneous differentiation process. The only exception was the $\mathrm{Na}^{+}$-independent transporter for neutral amino acids SLC43A1, which was upregulated in STB cells (Figure 2B).

Collectively, trophoblast differentiation under physiological conditions in vitro is predominantly characterized by an overexpression of several membrane transport proteins. Figure 3 further highlights the genes with the highest foldchange overexpression in STB $(\mathrm{FC}>2)$ comprising cholesterol efflux transporters (ABCA1, ABCG1), the drug transporter $\mathrm{ABCB} 1$, the oligopeptide transporter SLC15A1, the folate transporter SLC19A1, and several amino acid transporters (SLC3A1, SLC7A1, SLC7A9, SLC43A1).

\subsection{Protein Expression of Selected Membrane Transporters in Primary Trophoblast Cells}

Western blot analysis was performed to confirm whether the differential mRNA expression is also reflected at the protein level for representative genes of nutrient transport proteins. Cell lysates from the CTB and STB stage were incubated with antibodies encoding ABCA1, ABCG1, SLC2A1, SLC3A2, SLC7A5, and TfR1. Protein expression of ABCG1 (Figure 4B) and SLC3A2 (Figure 4D) was consistent with the findings from gene expression studies, showing significantly higher expression in the differentiated cell state. Contrary to mRNA levels, SLC7A5 (Figure 4E) and TfR1 (Figure 4F) protein expression was significantly upregulated upon trophoblast differentiation in vitro. On the other hand, ABCA1 (Figure 4A) and SLC2A1 (Figure 4C) protein expression seemed to be unaffected by the differentiation stage.

\subsection{Effect of Trophoblast Differentiation on Cholesterol Efflux and Leucine and Iron Uptake}

To investigate functional differences in the transporter activity between the CTB and STB stage, three representative essential substrates from the class of lipids (cholesterol), amino acids (leucine), and micronutrient (iron) transporters were selected. The efflux activity of ABCA1 and ABCG1 was determined by analyzing cholesterol transport in the presence of ApoA-I and $\mathrm{HDL}$, respectively. At a 6 - $\mathrm{h}$ incubation period, we observed higher ABCG1 (HDL-mediated) efflux activity in the STB stage (Figure 5B). On the other hand, ABCA1-mediated cholesterol to ApoA-I was not affected by the differentiation process (Figure 5A). Leucine and iron uptake was investigated in a time-dependent manner, revealing increased uptake over time in both CTB and STB cells; nonetheless, the uptake in the STB stage was significantly higher than CTB cells (Figures 5C,D).

\section{DISCUSSION}

Hormone synthesis and transplacental nutrient delivery comprise principal functions for optimal fetal growth and development (Costa 2016). The STB layer is the crucial structure implicated with maternal-fetal exchange due to its critical position and high metabolic rate (Carter 2000). On the contrary, the latest research has shown that the undifferentiated CTBs are the most metabolically active cells in the human term placenta, with a high fuel flexibility level (Kolahi et al., 2017). Deciphering the mechanisms which govern and/or are affected by trophoblast differentiation is crucial in the fundamental understanding of placental biology. This study provides a comprehensive evaluation of several endocrine and transport aspects associated with the differentiation of CTBs into STB (Figure 6).

Using qPCR analysis, we show that the STB stage is associated with upregulated gene expression of hCG, hPL, ENG, and CDH11. Upregulated hCG gene expression was further confirmed by hCG protein release in the cell supernatant. This is in line with reported literature using immunohistochemical analysis (MacCalman et al., 1996; Frank et al., 2001; Pötgens et al., 2003) and demonstrates the physiological characteristics of our in vitro model. Further, this finding identifies mRNA expression as an excellent means of determining the spontaneous syncytialization process of CTB in vitro. On the other hand, we report similar mRNA expression levels of MUC1 and ERVW- 

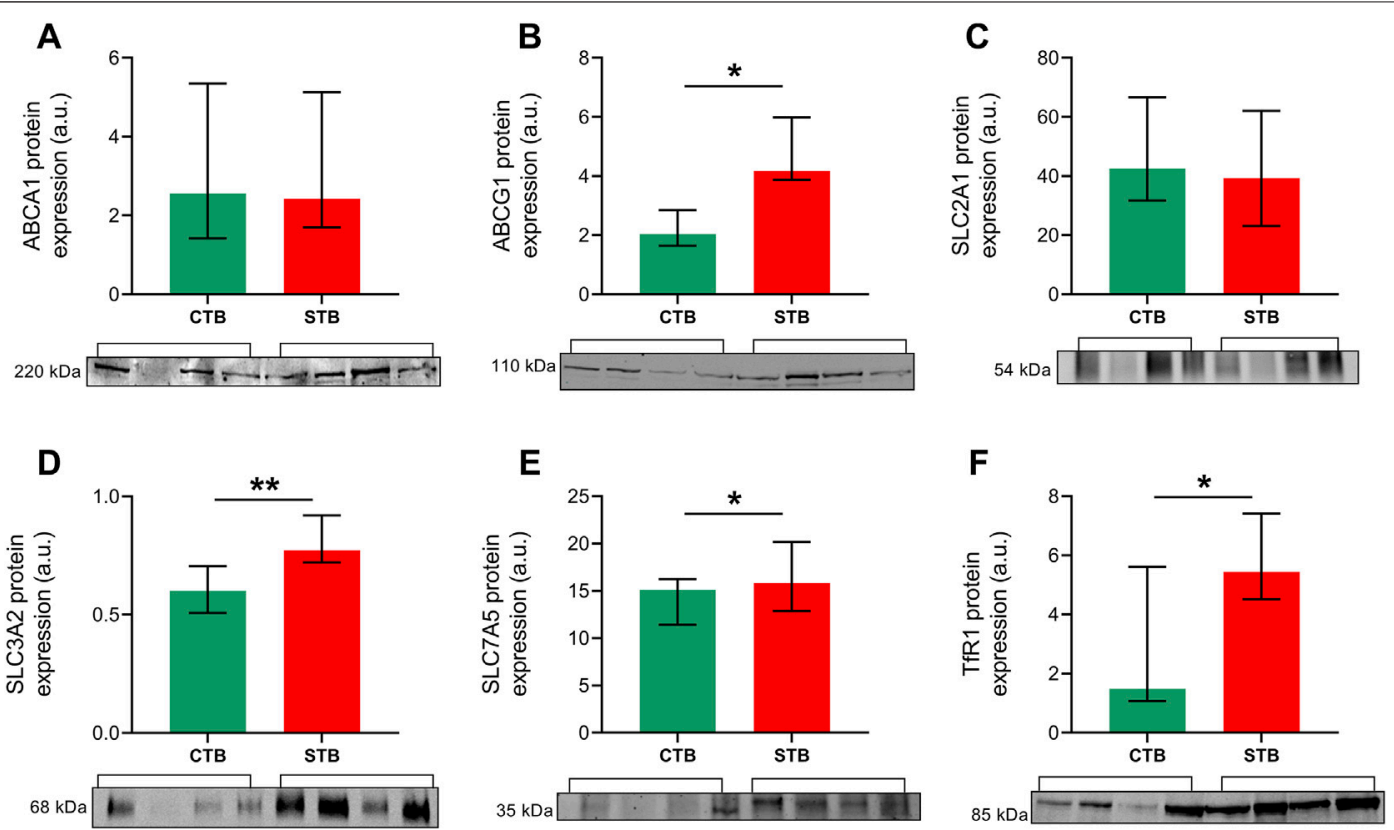

FIGURE 4 | Expression of selected proteins of interest in primary trophoblast cells. Western blot analysis was carried out to evaluate the protein expression of cholesterol efflux transporters ABCA1 (A) and ABCG1 (B), glucose uptake transporter SLC2A1 (C), 4F2 heavy chain SLC3A2 (D) and amino acid transporter SLC7A5 (E), and iron uptake receptor TfR1 (F). Protein expression was normalized to the total protein, as visualized by Ponceau S staining. Data are shown as median with IQR; $n=4$ for each stage. Asterisks indicate significance according to nonparametric $t$-test (Mann-Whitney test): ${ }^{\star} p \leq 0.05$, ${ }^{\star \star} p \leq 0.01$.

1 in freshly isolated CTBs and the multinucleated STB. MUC1 expression was previously described in both villous trophoblast cell populations (Jeschke et al., 2002); herein, we report that its mRNA expression is unaffected by CTB fusion. ERVW-1 expression in CTB cells, however, is not well described. Its expression has mainly been related to the STB layer, a phenomenon that appears paradoxical considering ERVW-1's in vitro cell-cell fusogenic activity (Pötgens et al., 2004). To this end, using RNA-Seq gene expression, Azar et al. recently reported down-regulated ERVW-1 in the STB cell stage (Azar et al., 2018). Importantly, ERVW-1 knockout mice show defective syncytial formation and placentation, overexpansion of CTBs, and die at midgestation (Dupressoir et al., 2009). Taken together, these findings and our data suggest that ERVW-1 is consistently expressed throughout the differentiation processes, and in the CTB stage, it plays an important role in cell fusion processes.

We have previously conveyed the expression of several membrane transporters in the BeWo cell line (before and after syncytialization with forskolin) and primary trophoblast cells (CTB and STB stage) (Kallol et al., 2018b). In the current study, we concentrate on primary trophoblast cells isolated from the human term placenta and investigate in detail the expression signature of thirty membrane nutrient transport proteins (Table 1) in a significantly larger dataset. We show that the STB stage is associated with upregulated gene expression of cholesterol efflux transporters. Cholesterol is an essential membrane component, a precursor of steroid hormones, and plays a crucial role in embryogenesis (Kallol and Albrecht 2020). Despite fetal cholesterol synthesizing capacity, maternal cholesterol remains a critical source for the fetus, and thus, maternal-to-fetal transport is essential (Woollett 2011). Maternal cholesterol is carried by lipoproteins such as LDL or HDL, taken up by respective receptors. Subsequently, cholesterol efflux from the cell is active and is mediated by ABCA1 and ABCG1 onto lipid-poor ApoA-I and HDL, respectively (Kallol and Albrecht 2020). We provide evidence that the STB cells display upregulated ABCA1 and ABCG1 gene expression, whereas only for ABCG1, this change is reflected in the protein level. These expression patterns were further accompanied by differential cholesterol efflux capacity.

Specifically, we show that ABCG1-mediated cholesterol efflux in STB (promoted by HDL) is significantly enhanced, whereas ABCA1-mediated transport (promoted by ApoA-I) is unaffected by the differentiation stage. Our observations are in line with the findings by Keelan et al., who showed that after a 72-h culture time (also used in our study), ABCA1 mRNA expression is significantly upregulated in the STB stage, whereas protein expression is unaltered (Keelan et al., 2011); nonetheless, the authors further report significantly increased ABCA1 protein after a $120-\mathrm{h}$ incubation period. It should be noted that cholesterol efflux is also significant during CTB differentiation, and ABCA1-deficient mice show significant placental malformations (Christiansen-Weber et al., 2000). Interestingly, ApoA-I release by primary trophoblast cells is also the highest at $24 \mathrm{~h}$ of culture (CTB stage) (Melhem et al., 2019). This suggests higher ApoA-I availability in the CTB cell phase, likely promoting ABCA1-mediated cholesterol efflux for processes within the undifferentiated cell. Indeed studies have shown that, in addition to transmembrane transport, ABCA1 also moves lipids within membranes to modulate cell proliferation and immunity (Nagao 

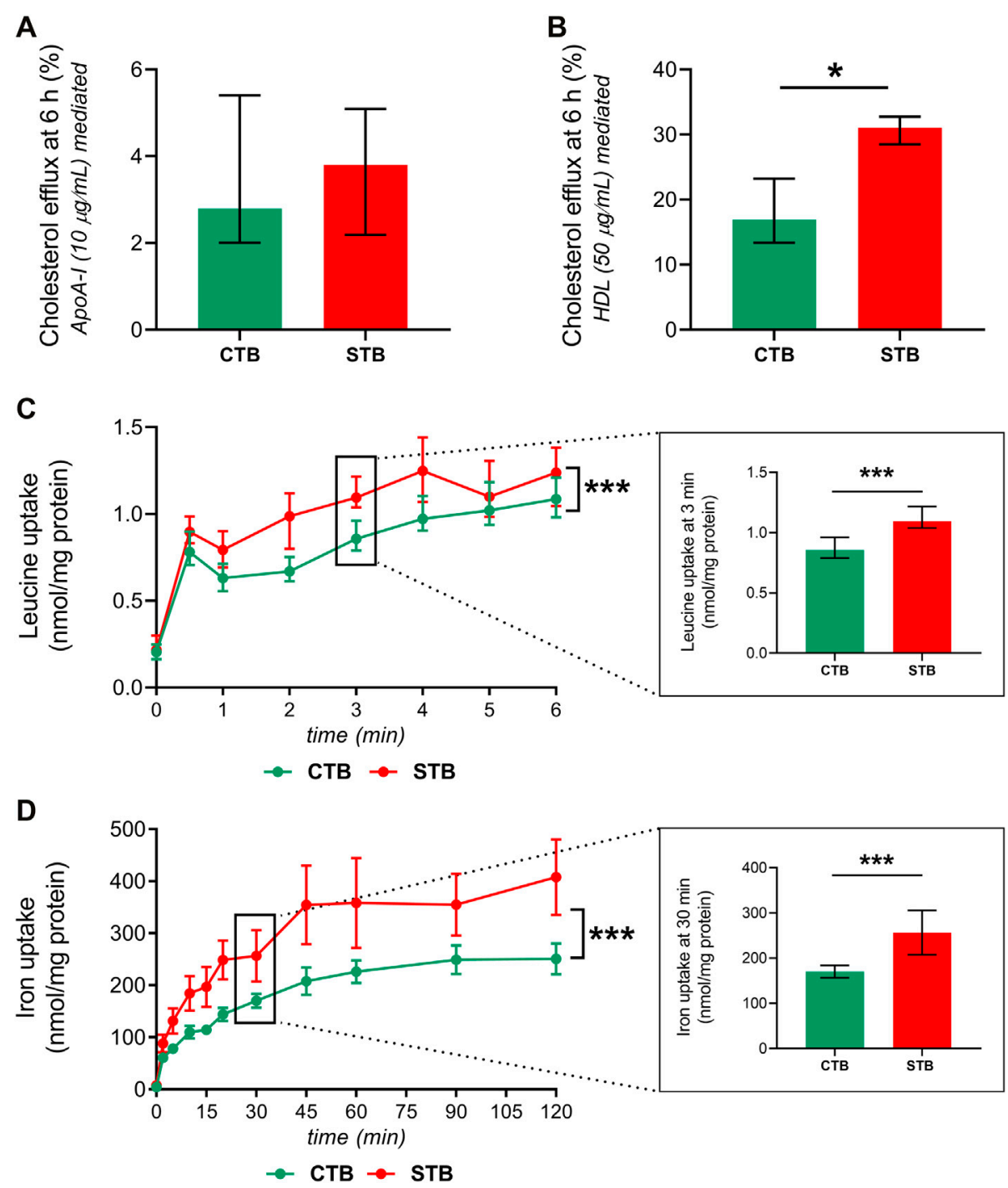

FIGURE 5 | Effect of trophoblast differentiation on the transport of cholesterol, leucine, and iron. CTB, $8 \mathrm{~h}$, and STB, $48 \mathrm{~h}$ after seeding, were incubated for $24 \mathrm{~h}$ with $\left[{ }^{3} \mathrm{H}\right]$-cholesterol $(0.5 \mu \mathrm{Ci} / \mathrm{ml})$. Subsequently, cholesterol efflux was evaluated in the presence of $10 \mu \mathrm{g} / \mathrm{ml}$ ApoA-I (A), ABCA1-mediated) and $50 \mu \mathrm{g} / \mathrm{ml} \mathrm{HDL}$ (B), ABCG1-mediated) for $6 \mathrm{~h}$. The efflux transporter activity is shown as the fraction of radioactive signal in the medium compared to the total signal in the medium and cells. Acceptor-mediated efflux is calculated by subtracting efflux without acceptor from efflux with the acceptor. Leucine (C), SLC7A5-mediated) and iron (D), TfR1mediated) uptake in CTB and STB was assessed in a time-dependent manner, and the results are shown in nmol/mg protein. Data are presented as median with IQR; $n \geq$ 3 for each stage. Asterisks indicate significance according to paired, nonparametric $t$-test (Wilcoxon test) or two-way ANOVA (for time-dependency studies): * $p \leq 0.05$, ${ }^{\star \star \star} p \leq 0.001$.

et al., 2011). Additionally, ABCA1 upregulation modifies cholesterol packaging in cell membranes, altering plasma membrane properties (Hassan et al., 2007), which may contribute to its potential involvement in cell fusion processes (Bocchetta et al., 2014).

The trophoblast syncytialization process was recently associated with the enrichment of genes involved in amino acid transport (Azar et al., 2018). We show that this primarily involves key transporters for cationic and large neutral amino acids (SLC7A1, SLC7A6, and SLC7A9), while the expression of anionic and neutral amino acid transporters is not significantly affected. Interestingly, we also observed that the heavy subunits for the heterodimeric amino acid transporters, SLC3A1 and
SLC3A2, are significantly upregulated during the in vitro trophoblast differentiation. The only amino acid transporter known to form heterodimer with SLC3A1 (also named rBAT) is SLC7A9 $\left(\mathrm{b}^{0,+} \mathrm{AT}\right)$ (Fotiadis et al., 2013). While the rBAT/ $\mathrm{b}^{0,+} \mathrm{AT}$ complex has been reported in the placenta (Feliubadaló et al., 1999), its functional impact remains undetermined. Nonetheless, the parallel increase in SLC3A1 and SLC7A9 mRNA expression during trophoblast differentiation suggests the potential importance of this complex in the STB stage and thus requires further investigation. On the other hand, SLC3A2 (also named $4 \mathrm{~F} 2 \mathrm{hc})$ forms heterodimers with a broader range of 


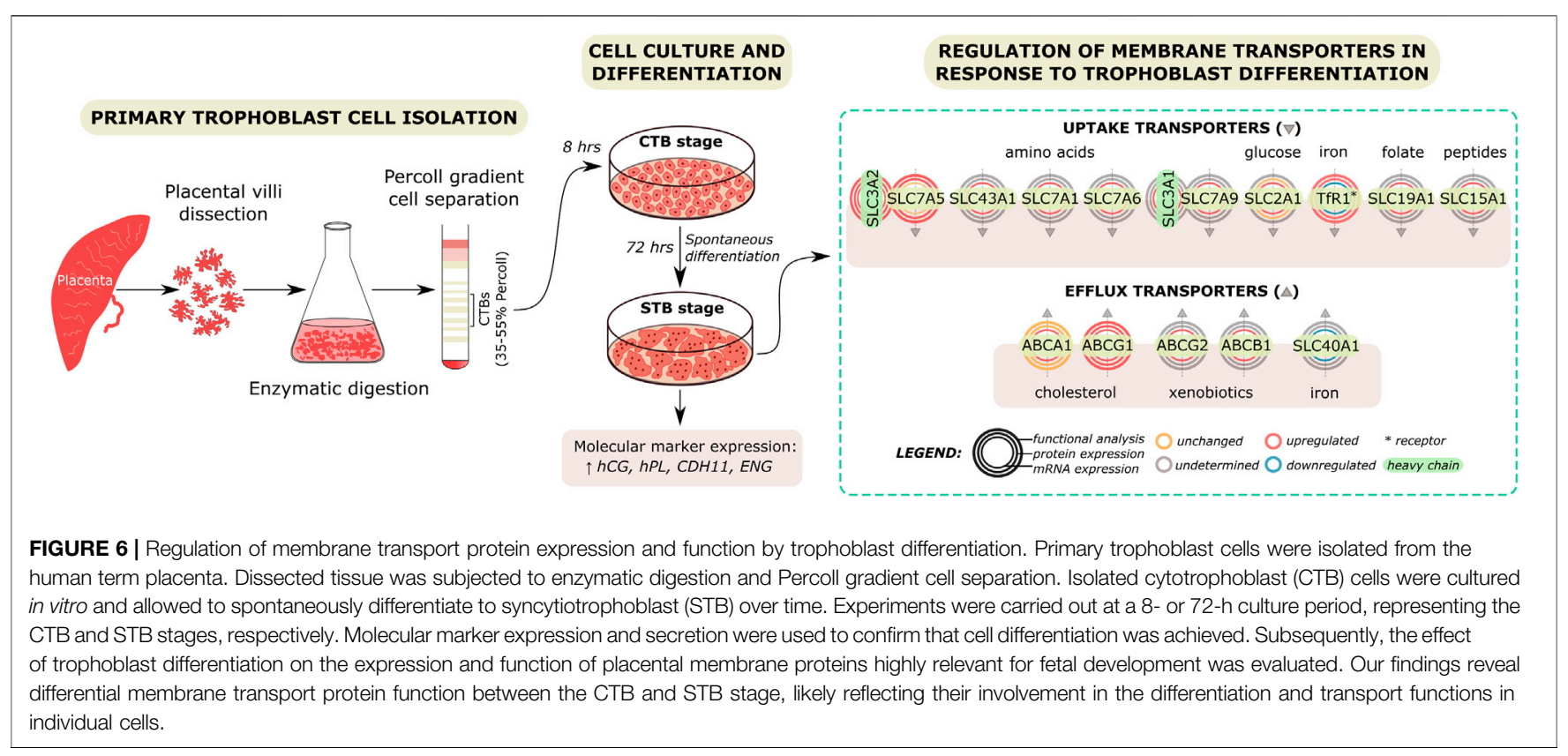

transporters from the SLC7A family, i.e., the neutral amino acid transporters (SLC7A5, SLC7A8), cationic and large neutral amino acid transporters (SLC7A6, SLC7A7), and the anionic amino acid transporter SLC7A11 (Fotiadis et al., 2013). In addition to its role in targeting these transporters, SLC3A2 has also been reported to exert cellular fusogenic and proliferative action (Cantor et al., 2009; Takesono et al., 2012). Recent work in trophoblast cells has highlighted the importance of SLC7A5 in supporting protein expression and membrane presentation of SLC3A2 for fusogenic activity (Ohgaki et al., 2017). To further understand the complex relationship between trophoblast differentiation and SLC7A5/3A2, we investigated their protein and functional expression in CTB and STB cells. In line with our previous reports (Zaugg et al., 2020a), we show that the expression of these proteins and uptake of leucine (SLC7A5 substrate) is significantly enhanced in STB compared to the CTB cells. These findings suggest that trophoblast differentiation is associated with a parallel upregulated transport capacity. Collectively, this phenomenon, previously also reported for other amino acid transport systems (Furesz et al., 1993), highlights the dominant role of STB in amino acid transfer across the placental barrier.

To support the fetal nutrient demands, pregnancy profoundly affects maternal physiology and metabolism, including iron homeostasis (Sangkhae and Nemeth 2019). Optimal iron nutrition is essential for fetal development and the establishment of iron stores upon delivery. The major maternal iron source is iron complexed with transferrin, whose uptake is mediated by transferrin receptor 1 (TfR1). Several other transport proteins (including SLC11A2, SLC40A1, SLC39A8, SLC39A14) are reportedly highly expressed in the placenta contributing to the maternal-to-fetal transfer of iron (Sangkhae and Nemeth 2019). Nonetheless, despite their vital importance, our understanding of iron transporter localization to the trophoblast cells remains limited. Here, we show that all investigated iron transport proteins are expressed in both CTB and STB cells. Interestingly, TfR1 mRNA expression showed downregulation upon trophoblast differentiation in vitro. To examine this further, protein expression and functional analysis of transferrin-mediated iron uptake were measured. Contrary to mRNA level, CTB differentiation to STB provoked expressional and functional upregulation in TfR1 protein. As TfR1 represents a key player in iron transport, these findings suggest that the STB is the principal placental cell mediating transplacental iron delivery to the fetus.

In conclusion, this study yields new insights into the cellular functions associated with or altered by trophoblast fusion. Quantitative PCR analysis was applied as a screening method for differential mRNA expression of several classes of nutrient and drug transport genes associated with trophoblast syncytialization. However, we were limited in addressing protein and functional alterations of all transporters investigated. As such, it is the first step in understanding the physiological functions linking placental transport function with trophoblast differentiation. The abnormal trophoblast differentiation process has been proposed as a potential mechanism underlying the pathophysiology of several placental pathologies (Huppertz 2011; Szilagyi et al., 2020). Defective syncytialization could lead to nutrient transfer imbalance, ultimately compromising fetal development and programming. Therefore, our findings are relevant to several studies indicating altered placental transport in pregnancy-associated conditions (Desoye et al., 2011; Huang et al., 2018; Zaugg et al., 2020b). Importantly, with a large number of transporters currently reported in the human placenta, future studies should focus on deciphering the expression patterns in trophoblast cells and their involvement in cellular functions. Knowledge of this nature may potentially facilitate the development of treatment strategies in pregnancy complications associated with these transport proteins. 


\section{DATA AVAILABILITY STATEMENT}

The original contributions presented in the study are included in the article/Supplementary Material, further inquiries can be directed to the corresponding author.

\section{ETHICS STATEMENT}

The study was performed according to the Declaration of Helsinki, with the approval of the Ethics Committee of the Canton of Bern (Basec Nr. 2016-00250). The patients provided their written informed consent to participate in this study.

\section{AUTHOR CONTRIBUTIONS}

SK and CA participated in the study concept and design. JZ, SK, $\mathrm{BF}$, and RK contributed to the data acquisition. RK, JZ, BF, and SK performed the data analysis and interpreted the results. $\mathrm{RMH}$ recruited patients and provided patient data. FS contributed to the interpretation of results. RK wrote the article. CA supervised the project. All authors read and approved the final manuscript.

\section{REFERENCES}

Apáti, Á., Szebényi, K., Erdei, Z., Várady, G., Orbán, T. I., and Sarkadi, B. (2016). The Importance of Drug Transporters in Human Pluripotent Stem Cells and in Early Tissue Differentiation. Expert Opin. Drug Metab. Toxicol. 12 (1), 77-92. doi:10.1517/17425255.2016.1121382

Azar, C., Valentine, M., Trausch-Azar, J., Druley, T., Nelson, D. M., and Schwartz, A. L. (2018). RNA-seq Identifies Genes Whose Proteins Are Transformative in the Differentiation of Cytotrophoblast to Syncytiotrophoblast, in Human Primary Villous and BeWo Trophoblasts. Sci. Rep. 8 (1), 5142. doi:10.1038/ s41598-018-23379-2

Balkovetz, D. F., Tiruppathi, C., Leibach, F. H., Mahesh, V. B., and Ganapathy, V. (1989). Evidence for an Imipramine-Sensitive Serotonin Transporter in Human Placental Brush-Border Membranes. J. Biol. Chem. 264 (4), 2195-2198. doi:10. 1016/s0021-9258(18)94161-x

Barker, D. J. P., Godfrey, K. M., Gluckman, P. D., Harding, J. E., Owens, J. A., and Robinson, J. S. (1993). Fetal Nutrition and Cardiovascular Disease in Adult Life. The Lancet. 341 (8850), 938-941. doi:10.1016/0140-6736(93)91224-a

Barker, J. P. D., Eriksson, G. J., Kajantie, E., Alwasel, H. S., Fall, H. D. C., Roseboom, J. T., et al. (2010). The Placenta and Human Developmental Programming. Cambridge: Cambridge University Press.

Bloise, E., Ortiga-Carvalho, T. M., Reis, F. M., Lye, S. J., Gibb, W., and Matthews, S. G. (2016). ATP-Binding Cassette Transporters in Reproduction: a New Frontier. Hum. Reprod. Update. 22 (2), 164-181. doi:10.1093/humupd/dmv049

Bocchetta, S., Maillard, P., Yamamoto, M., Gondeau, C., Douam, F., Lebreton, S., et al. (2014). Up-Regulation of the ATP-Binding Cassette Transporter A1 Inhibits Hepatitis C Virus Infection. PLOS ONE. 9 (3), e92140. doi:10.1371/ journal.pone.0092140

Bodoy, S., Fotiadis, D., Stoeger, C., Kanai, Y., and Palacín, M. (2013). The Small SLC43 Family: Facilitator System L Amino Acid Transporters and the Orphan EEG1. Mol. Aspects Med. 34 (2-3), 638-645. doi:10.1016/j.mam.2012.12.006

Burton, G. J., and Fowden, A. L. (2015). The Placenta: a Multifaceted, Transient Organ. Phil. Trans. R. Soc. B. 370 (1663), 20140066. doi:10.1098/rstb.2014.0066 Cantor, J., Browne, C. D., Ruppert, R., Féral, C. C., Fässler, R., Rickert, R. C., et al. (2009). CD98hc Facilitates B Cell Proliferation and Adaptive Humoral Immunity. Nat. Immunol. 10 (4), 412-419. doi:10.1038/ni.1712

\section{FUNDING}

This study was financially supported by the Swiss National Science Foundation (Grant No. 310030_149,958), the National Center of Competence in Research (NCCR) TransCure, University of Bern, Switzerland (Grant No. 51NF40-185544), and the Lindenhof Foundation, Bern, Switzerland (Grant No. 17-15-F).

\section{ACKNOWLEDGMENTS}

We would like to thank the patients, physicians, and midwives from Lindenhofgruppe, Bern, Switzerland, for participating in the study. Michael Lüthi and Edgar Ontsouka are acknowledged for expert help in the lab and fruitful scientific discussions.

\section{SUPPLEMENTARY MATERIAL}

The Supplementary Material for this article can be found online at: https://www.frontiersin.org/articles/10.3389/fcell.2022.820286/ full\#supplementary-material

Carter, A. M. (2000). Placental Oxygen Consumption. Part I: In Vivo Studies-A Review. Placenta. 21 (Suppl. A), S31-S37. doi:10.1053/plac.1999.0513

Christiansen-Weber, T. A., Voland, J. R., Wu, Y., Ngo, K., Roland, B. L., Nguyen, S., et al. (2000). Functional Loss of ABCA1 in Mice Causes Severe Placental Malformation, Aberrant Lipid Distribution, and Kidney Glomerulonephritis as Well as High-Density Lipoprotein Cholesterol Deficiency. Am. J. Pathol. 157 (3), 1017-1029. doi:10.1016/s0002-9440(10)64614-7

Cleal, J. K., Lofthouse, E. M., Sengers, B. G., and Lewis, R. M. (2018). A Systems Perspective on Placental Amino Acid Transport. J. Physiol. 596 (23), 5511-5522. doi:10.1113/jp274883

Costa, M. A. (2016). The Endocrine Function of Human Placenta: an Overview. Reprod. BioMedicine Online. 32 (1), 14-43. doi:10.1016/j.rbmo.2015.10.005

Dallmann, A., Liu, X. I., Burckart, G. J., and van den Anker, J. (2019). Drug Transporters Expressed in the Human Placenta and Models for Studying Maternal-Fetal Drug Transfer. J. Clin. Pharmacol. 59 (Suppl. 1), S70-S81. doi:10.1002/jcph.1491

Desoye, G., Gauster, M., and Wadsack, C. (2011). Placental Transport in Pregnancy Pathologies. Am. J. Clin. Nutr. 94 (6 Suppl. 1), 1896s-1902s. doi:10.3945/ajcn.110.000851

Dupressoir, A., Vernochet, C., Bawa, O., Harper, F., Pierron, G., Opolon, P., et al. (2009). Syncytin-A Knockout Mice Demonstrate the Critical Role in Placentation of a Fusogenic, Endogenous Retrovirus-Derived, Envelope Gene. Proc. Natl. Acad. Sci. 106 (29), 12127-12132. doi:10.1073/pnas. 0902925106

Evseenko, D. A., Paxton, J. W., and Keelan, J. A. (2006). ABC Drug Transporter Expression and Functional Activity in Trophoblast-Like Cell Lines and Differentiating Primary Trophoblast. Am. J. Physiology-Regulatory, Integr. Comp. Physiol. 290 (5), R1357-R1365. doi:10.1152/ajpregu.00630.2005

Feliubadaló, L., Font, M., Purroy, J., Rousaud, F., Estivill, X., Nunes, V., et al. (1999). Non-type I Cystinuria Caused by Mutations in SLC7A9, Encoding a Subunit (bo,+AT) of rBAT. Nat. Genet. 23 (1), 52-57. doi:10.1038/12652

Fotiadis, D., Kanai, Y., and Palacín, M. (2013). The SLC3 and SLC7 Families of Amino Acid Transporters. Mol. Aspects Med. 34 (2-3), 139-158. doi:10.1016/j. mam.2012.10.007

Frank, H.-G., Morrish, D. W., Pötgens, A., Genbacev, O., Kumpel, B., and Caniggia, I. (2001). Cell Culture Models of Human Trophoblast: Primary Culture of Trophoblast-A Workshop Report. Placenta. 22, S107-S109. doi:10.1053/plac. 2001.0644 
Fuenzalida, B., Cantin, C., Kallol, S., Carvajal, L., Pastén, V., Contreras-Duarte, S., et al. (2020). Cholesterol Uptake and Efflux Are Impaired in Human Trophoblast Cells from Pregnancies with Maternal Supraphysiological Hypercholesterolemia. Sci. Rep. 10 (1), 5264. doi:10.1038/s41598-020-61629-4

Fuenzalida, B., Sobrevia, B., Cantin, C., Carvajal, L., Salsoso, R., Gutiérrez, J., et al. (2018). Maternal Supraphysiological Hypercholesterolemia Associates with Endothelial Dysfunction of the Placental Microvasculature. Sci. Rep. 8 (1), 7690. doi:10.1038/s41598-018-25985-6

Furesz, T. C., Smith, C. H., and Moe, A. J. (1993). ASC System Activity Is Altered by Development of Cell Polarity in Trophoblast from Human Placenta. Am. J. Physiol. 265 (1 Pt 1), C212-C217. doi:10.1152/ajpcell.1993.265.1.C212

Gaccioli, F., Lager, S., Powell, T. L., and Jansson, T. (2013). Placental Transport in Response to Altered Maternal Nutrition. J. Dev. Orig Health Dis. 4 (2), 101-115. doi:10.1017/s2040174412000529

Gambling, L., Danzeisen, R., Gair, S., Lea, R. G., Charania, Z., Solanky, N., et al. (2001). Effect of Iron Deficiency on Placental Transfer of Iron and Expression of Iron Transport Proteins In Vivo and In Vitro. Biochem. J. 356 (Pt 3), 883-889. doi:10.1042/0264-6021:3560883

Häfliger, P., Graff, J., Rubin, M., Stooss, A., Dettmer, M. S., Altmann, K.-H., et al. (2018). The LAT1 Inhibitor JPH203 Reduces Growth of Thyroid Carcinoma in a Fully Immunocompetent Mouse Model. J. Exp. Clin. Cancer Res. 37 (1), 234. doi:10.1186/s13046-018-0907-z

Hassan, H. H., Denis, M., Lee, D.-Y. D., Iatan, I., Nyholt, D., Ruel, I., et al. (2007). Identification of an ABCA1-Dependent Phospholipid-Rich Plasma Membrane Apolipoprotein A-I Binding Site for Nascent HDL Formation: Implications for Current Models of HDL Biogenesis. J. Lipid Res. 48 (11), 2428-2442. doi:10. 1194/jlr.m700206-jlr200

Huang, X., Anderle, P., Hostettler, L., Baumann, M. U., Surbek, D. V., Ontsouka, E. C., et al. (2018). Identification of Placental Nutrient Transporters Associated with Intrauterine Growth Restriction and Pre-Eclampsia. BMC Genomics. 19 (1), 173. doi:10.1186/s12864-018-4518-z

Huppertz, B. (2006). Molecular Markers for Human Placental Investigation. Methods Mol. Med. 121, 337-350. doi:10.1385/1-59259-983-4:335

Huppertz, B. (2011). Trophoblast Differentiation, Fetal Growth Restriction and preeclampsiaPregnancy Hypertension. Pregnancy Hypertens. Int. J. Women's Cardiovasc. Health. 1 (1), 79-86. doi:10.1016/j.preghy.2010.10.003

Illsley, N. P. (2000). CURRENT TOPIC: Glucose Transporters in the Human Placenta. Placenta. 21 (1), 14-22. doi:10.1053/plac.1999.0448

Jeong, J., and Eide, D. J. (2013). The SLC39 Family of Zinc Transporters. Mol. Aspects Med. 34 (2-3), 612-619. doi:10.1016/j.mam.2012.05.011

Jeschke, U., Richter, D., Hammer, A., Briese, V., Friese, K., and Karsten, U. (2002). Expression of the Thomsen-Friedenreich Antigen and of its Putative Carrier Protein Mucin 1 in the Human Placenta and in Trophoblast Cells In Vitro. Histochem. Cel Biol. 117 (3), 219-226. doi:10.1007/s00418-002-0383-5

Kallol, S., Huang, X., Müller, S., Ontsouka, C. E., and Albrecht, C. (2018a). Novel Insights into Concepts and Directionality of Maternal-Fetal Cholesterol Transfer across the Human Placenta. Int. J. Mol. Sci. 19 (8), 2334. doi:10. 3390/ijms19082334

Kallol, S., Moser-Haessig, R., Ontsouka, C. E., and Albrecht, C. (2018b). Comparative Expression Patterns of Selected Membrane Transporters in Differentiated BeWo and Human Primary Trophoblast Cells. Placenta. 7273, 48-52. doi:10.1016/j.placenta.2018.10.008

Kallol, S., and Albrecht, C. (2020). Materno-fetal Cholesterol Transport during Pregnancy. Biochem. Soc. Trans. 48 (3), 775-786. doi:10.1042/ bst20190129

Kanai, Y., Clémençon, B., Simonin, A., Leuenberger, M., Lochner, M., Weisstanner, M., et al. (2013). The SLC1 High-Affinity Glutamate and Neutral Amino Acid Transporter Family. Mol. Aspects Med. 34 (2-3), 108-120. doi:10.1016/j.mam. 2013.01.001

Keelan, J. A., Aye, I. L. M. H., Mark, P. J., and Waddell, B. J. (2011). ABCA1 and Placental Cholesterol Efflux. Placenta. 32 (9), 708-709. doi:10.1016/j.placenta. 2011.06.004

Kliman, H. J., Nestler, J. E., Sermasi, E., Sanger, J. M., and Strauss, J. F., 3rd (1986). Purification, Characterization, Andin vitroDifferentiation of Cytotrophoblasts from Human Term Placentae. Endocrinology. 118 (4), 1567-1582. doi:10.1210/ endo-118-4-1567

Knöfler, M., Haider, S., Saleh, L., Pollheimer, J., Gamage, T. K. J. B., and James, J. (2019). Human Placenta and Trophoblast Development: Key Molecular
Mechanisms and Model Systems. Cell. Mol. Life Sci. 76 (18), 3479-3496. doi:10.1007/s00018-019-03104-6

Koepsell, H. (2020). Organic Cation Transporters in Health and Disease. Pharmacol. Rev. 72 (1), 253-319. doi:10.1124/pr.118.015578

Kolahi, K. S., Valent, A. M., and Thornburg, K. L. (2017). Cytotrophoblast, Not Syncytiotrophoblast, Dominates Glycolysis and Oxidative Phosphorylation in Human Term Placenta. Sci. Rep. 7, 42941. doi:10.1038/srep42941

MacCalman, C. D., Furth, E. E., Omigbodun, A., Bronner, M., Coutifaris, C., and Strauss, J. F., 3rd (1996). Regulated Expression of Cadherin-11 in Human Epithelial Cells: a Role for Cadherin-11 in Trophoblast-Endometrium Interactions. Dev. Dyn. 206 (2), 201-211. doi:10.1002/(sici)10970177(199606)206:2<201:aid-aja9>3.0.co;2-m

Melhem, H., Kallol, S., Huang, X., Lüthi, M., Ontsouka, C. E., Keogh, A., et al. (2019). Placental Secretion of Apolipoprotein A1 and E: the Anti-Atherogenic Impact of the Placenta. Sci. Rep. 9 (1), 6225. doi:10.1038/s41598-019-42522-1

Montalbetti, N., Simonin, A., Kovacs, G., and Hediger, M. A. (2013). Mammalian Iron Transporters: Families SLC11 and SLC40. Mol. Aspects Med. 34 (2-3), 270-287. doi:10.1016/j.mam.2013.01.002

Nagao, K., Tomioka, M., and Ueda, K. (2011). Function and Regulation of ABCA1 - Membrane Meso-Domain Organization and Reorganization. FEBS J. 278 (18), 3190-3203. doi:10.1111/j.1742-4658.2011.08170.x

Napolitano, L., Scalise, M., Galluccio, M., Pochini, L., Albanese, L. M., and Indiveri, C. (2015). LAT1 Is the Transport Competent Unit of the LAT1/CD98 Heterodimeric Amino Acid Transporter. Int. J. Biochem. Cel Biol. 67, 25-33. doi:10.1016/j.biocel.2015.08.004

Ohgaki, R., Ohmori, T., Hara, S., Nakagomi, S., Kanai-Azuma, M., KanedaNakashima, K., et al. (2017). Essential Roles of L-type Amino Acid Transporter 1 in Syncytiotrophoblast Development by Presenting Fusogenic 4F2hc. Mol. Cel Biol. 37 (11), e00427-00416. doi:10.1128/ MCB.00427-16

Pötgens, A. J. G., Drewlo, S., Kokozidou, M., and Kaufmann, P. (2004). Syncytin: the Major Regulator of Trophoblast Fusion? Recent Developments and Hypotheses on its Action. Hum. Reprod. Update. 10 (6), 487-496. doi:10. 1093/humupd/dmh039

Pötgens, A. J., Kataoka, H., Ferstl, S., Frank, H. G., and Kaufmann, P. (2003). A Positive Immunoselection Method to Isolate Villous Cytotrophoblast Cells from First Trimester and Term Placenta to High Purity. Placenta. 24 (4), 412-423. doi:10.1053/plac.2002.0914

Sangkhae, V., and Nemeth, E. (2019). Placental Iron Transport: The Mechanism and Regulatory Circuits. Free Radic. Biol. Med. 133, 254-261. doi:10.1016/j. freeradbiomed.2018.07.001

Sata, R., Ohtani, H., Tsujimoto, M., Murakami, H., Koyabu, N., Nakamura, T., et al. (2005). Functional Analysis of Organic Cation Transporter 3 Expressed in Human Placenta. J. Pharmacol. Exp. Ther. 315 (2), 888-895. doi:10.1124/jpet. 105.086827

Scalise, M., Galluccio, M., Console, L., Pochini, L., and Indiveri, C. (2018). The Human SLC7A5 (LAT1): The Intriguing Histidine/Large Neutral Amino Acid Transporter and its Relevance to Human Health. Front. Chem. 6, 243. doi:10. 3389/fchem.2018.00243

Schiöth, H. B., Roshanbin, S., Hägglund, M. G., and Fredriksson, R. (2013). Evolutionary Origin of Amino Acid Transporter Families SLC32, SLC36 and SLC38 and Physiological, Pathological and Therapeutic Aspects. Mol. Aspects Med. 34 (2-3), 571-585. doi:10.1016/j.mam.2012.07.012

Smith, D. E., Clémençon, B., and Hediger, M. A. (2013). Proton-coupled Oligopeptide Transporter Family SLC15: Physiological, Pharmacological and Pathological Implications. Mol. Aspects Med. 34 (2-3), 323-336. doi:10.1016/j.mam.2012.11.003

Sreckovic, I., Birner-Gruenberger, R., Obrist, B., Stojakovic, T., Scharnagl, H., Holzer, M., et al. (2013). Distinct Composition of Human Fetal HDL Attenuates its Anti-Oxidative Capacity. Biochim. Biophys. Acta (Bba) - Mol. Cel Biol. Lipids. 1831 (4), 737-746. doi:10.1016/j.bbalip.2012.12.015

Szilagyi, A., Gelencser, Z., Romero, R., Xu, Y., Kiraly, P., Demeter, A., et al. (2020). Placenta-Specific Genes, Their Regulation during Villous Trophoblast Differentiation and Dysregulation in Preterm Preeclampsia. Int. J. Mol. Sci. 21 (2), 628. doi:10.3390/ijms21020628

Takesono, A., Moger, J., Farooq, S., Cartwright, E., Dawid, I. B., Wilson, S. W., et al. (2012). Solute Carrier Family 3 Member 2 (Slc3a2) Controls Yolk Syncytial Layer (YSL) Formation by Regulating Microtubule Networks in the Zebrafish Embryo. Proc. Natl. Acad. Sci. 109 (9), 3371-3376. doi:10.1073/pnas.1200642109 
Vähäkangas, K. H., Veid, J., Karttunen, V., Partanen, H., Sieppi, E., Kummu, M., et al. (2011). "Chapter 79 - the Significance of ABC Transporters in Human Placenta for the Exposure of the Fetus to Xenobiotics," in Reproductive and Developmental Toxicology. Editor R. C. Gupta (San Diego: Academic Press), 1051-1065.

Vähäkangas, K., and Myllynen, P. (2009). Drug Transporters in the Human BloodPlacental Barrier. Br. J. Pharmacol. 158 (3), 665-678. doi:10.1111/j.1476-5381. 2009.00336.x

Walker, N., Filis, P., Soffientini, U., Bellingham, M., O'Shaughnessy, P. J., and Fowler, P. A. (2017). Placental Transporter Localization and Expression in the Human: the Importance of Species, Sex, and Gestational Age Differences $\dagger$. Biol. Reprod. 96 (4), 733-742. doi:10.1093/biolre/iox012

Woollett, L. A. (2011). Review: Transport of Maternal Cholesterol to the Fetal Circulation. Placenta. 32 (Suppl. 2), S218-S221. doi:10.1016/j.placenta.2011. 01.011

Zaugg, J., Huang, X., Ziegler, F., Rubin, M., Graff, J., Müller, J., et al. (2020a). Small Molecule Inhibitors Provide Insights into the Relevance of LAT1 and LAT2 in Materno-foetal Amino Acid Transport. J. Cel. Mol. Med. 24 (21), 12681-12693. doi: $10.1111 /$ jcmm.15840

Zaugg, J., Melhem, H., Huang, X., Wegner, M., Baumann, M., Surbek, D., et al. (2020b). Gestational Diabetes Mellitus Affects Placental Iron Homeostasis: Mechanism and Clinical Implications. FASEB j. 34 (6), 7311-7329. doi:10.1096/ fj.201903054r

Zaugg, J., Ziegler, F., Nuoffer, J.-M., Moser-Hässig, R., and Albrecht, C. (2021). Counter-directed Leucine Gradient Promotes Amino Acid Transfer across the Human Placenta. J. Nutr. Biochem. 96, 108760. doi:10.1016/j.jnutbio.2021.108760
Zhang, Y., Zhang, Y., Sun, K., Meng, Z., and Chen, L. (2018). The SLC Transporter in Nutrient and Metabolic Sensing, Regulation, and Drug Development. J. Mol. Cel Biol. 11 (1), 1-13. doi:10.1093/jmcb/ mjy052

Zhao, R., and Goldman, I. D. (2013). Folate and Thiamine Transporters Mediated by Facilitative Carriers (SLC19A1-3 and SLC46A1) and Folate Receptors. Mol. Aspects Med. 34 (2-3), 373-385. doi:10.1016/j.mam.2012. 07.006

Conflict of Interest: The authors declare that the research was conducted in the absence of any commercial or financial relationships that could be construed as a potential conflict of interest.

Publisher's Note: All claims expressed in this article are solely those of the authors and do not necessarily represent those of their affiliated organizations, or those of the publisher, the editors, and the reviewers. Any product that may be evaluated in this article, or claim that may be made by its manufacturer, is not guaranteed or endorsed by the publisher.

Copyright (c) 2022 Karahoda, Zaugg, Fuenzalida, Kallol, Moser-Haessig, Staud and Albrecht. This is an open-access article distributed under the terms of the Creative Commons Attribution License (CC BY). The use, distribution or reproduction in other forums is permitted, provided the original author(s) and the copyright owner(s) are credited and that the original publication in this journal is cited, in accordance with accepted academic practice. No use, distribution or reproduction is permitted which does not comply with these terms. 